\section{Geologists' Association response}

SIR - Des Griffin in his letter ${ }^{1}$ on the rumpus over the Natural History Museum's corporate plan is quite categoric. "The problem is the British government and its continued refusal to recognize the enormous importance of museums in all areas of science and education." He asks how the Geologists' Association would approach the problem - "presumably 132 years have taught them something". Quite so.

First, it is evident that if government does not recognize the importance of museum research, it is because it does not understand it. If it does not understand, it can only be because no-one has taken the trouble to explain it in language it can understand. The responsibility lies with the scientific community, not the government.

I should like, as president of the Geologists' Association, to outline the role it has played. The crisis over support for taxonomic research at the Natural History Museum is part of a much broader issue, as Griffin clearly perceives. All governments find it difficult to justify extensive financial support for long-term strategic research, data-gathering and geological surveying as well as taxonomy of animals, plants and fossils. Pure or 'blue skies' research and applied research they can grasp.

Whenever the funding of research has been discussed by bodies such as the Centre for Policy Studies, I have stressed the need for adequate support of such long-term data-collecting research.

In October last year, the Institute of Economic Affairs (IAE) Education Unit (a think-tank with the reputation of originating government economic policies) held a conference on the funding of research ${ }^{2}$, whose purpose was to formulate a policy for consideration by government ministers. The conference was concerned not with political issues but with finding the best and most effective way of supporting research.

I spoke on the problems of funding long-term strategic research, using as examples the work of the Geological Survey and the Natural History Museum, and my case was incorporated in the final conclusions of the conference:

"There is a whole area of research devoted to data collection. Some describe this as 'strategic research' ... Examples of data collecting research are the Natural History Museum with its wealth of data, and continuing collection of data, about all aspects of the animal kingdom. Such data collection, be it the examination of different species of fly or the varying composition of the atmospheric gases above the pole, may seem to have no immediate or obvious application, but such data, in all areas of science, is fundamental to research in those areas. Such data collection forms the 'dicresearchers can build.

"This area of research risks being neglected in our funding arrangements. It has to be funded with taxpayers money, nobody else today will fund it, and needs to be funded through the research councils or specifically and directly by the government.

"Even this area of research does produce an important economic return, but such is in general at one remove, it is usually not direct and not immediate."

It was at this point that the museum's corporate plan, with its deliberate decision that the scientific side should bear the brunt of the cuts, was launched on an unsuspecting world. In letters to the press, interviews and subsequent articles ${ }^{3}$, I have drawn attention to the advice proffered to the government by its own think-tank.

As president of the Geologists' Association, I wrote to the prime minister and several of her ministers, to every member of the museum's trustees and to presidents of other learned societies. The last resulted in a joint letter to the press, requesting that the scientific redundancies be held in abeyance until the government's science-funding policy had been finally decided, on the basis of the IEA deliberations.

Meanwhile, I appealed to all members of the Geologists' Association to protest to the government and to their own Members of Parliament. The minister responsible was left in no doubt as to the deep feelings regarding the imminent demise of major areas of geology and palaeontology.

Time will tell whether or not our strategy was the correct one. I leave it to your readers to judge whether Beverly Halstead has "done little to help the museum by his recent comments".

BEVERLY HALSTEAD (President)

Geologists' Association, Burlington House,

Piccadilly,

London W1V 9AG, UK.

1. Griffin, D. Nature 346, 99; (1990)

. Sexton, S. (ed.) The Funding of Research (Institute of Economic Affairs Education Unit, London, 1990).

3. Daily Telegraph 27 April; Times 27 April; Guardian 28 April; Science 11 May: Guardian 11 May; independent 14 May (1990).

4. Independent 25 May (1990)

SIR-Des Griffin's letter confuses me. I am not sure whether he supports Neil Chalmers, the director of the Natural History Museum, perhaps from the viewpoint of a museum director himself, or whether he is critical of the museum's corporate plan, and if so, on which grounds.

$\mathrm{He}$ accuses me of ignorant nonsense. But Griffin's musings (they are not logical tionary' of the subject upon which other arguments) do betray a touching political naivety, suffused with an inability to distinguish between the building called "the Natural History Museum", the existence of which is not at risk, and the functions within that building, which are not only at risk but are being destroyed at this very minute.

His senior-statesmanlike plea for joint pressure on the government presupposes that there is time. There is no time; staff morale is non-existent, staff are leaving even if their names are not on the redundancy list. The staff's request for reallocation of redundancies and jobs, published in the same issue as Griffin's letter, is inadequate.

I have no realistic solution to offer. Money is one problem, both now and for the future. The British government has not shown itself to be sympathetic to any organization that promotes public service as opposed to private profit. Like all governments, in the absence of internal motivation, the only thing it responds to is public pressure. These draft letters which Griffin disparages are part of this public pressure. The other problem is the attitude of management. Both problems need to be tackled at the same time. Considerably more public pressure is needed both from professionals and from the public for whose benefit the museum and its research staff exist.

There is a possible final solution which would perhaps meet with Griffin's approbation. It is not inconceivable that the collections and those research staff still remaining could be moved out of London and the museum in all senses handed over to Disneyland to do with as it pleases.

JOHN M. EVANS (Senior Vice-President)

Geologists' Association,

Burlington House,

Piccadilly, London W1V 9AG, UK

\section{Creating havoc}

SIR - I was interested in the close juxtaposition in Nature for 5 July of the reports of the flaw in one of the Hubble Space Telescope's (HST) mirrors (page 3) and the letter from Christopher Lote (page 10) on scientists' view on the existence of God.

It is my understanding that one of the possible uses of HST was to throw light on the creation of the Universe. Perhaps God does not want us to know.

114 Banbury Road,

GILBERT F. RICHARDS

Oxford OX2 6JU, UK

\section{Correction}

The author of the first letter headed "Manned mission to Mars" in the issue of 28 June (Nature 345, 760; 1990) is N. H. Horowitz. We regret having misspelled his name.

NATURE $\cdot$ VOL $346 \cdot 2$ AUGUST 1990 